\title{
Expression of Annexin-A1 and Galectin-1 Anti-Inflammatory Proteins and mRNA in Chronic Gastritis and Gastric Cancer
}

\author{
Yvana Cristina Jorge, ${ }^{1}$ Mayra Mioto Mataruco, ${ }^{1}$ Leandro Pires Araújo,, \\ Ana Flávia Teixeira Rossi, ${ }^{1}$ Juliana Garcia de Oliveira, ${ }^{1}$ Marina Curado Valsechi, ${ }^{1}$ \\ Alaor Caetano, ${ }^{2}$ Kenji Miyazaki, ${ }^{3}$ Célia Sebastiana de Jesus Fazzio, ${ }^{4}$ \\ Jorge Alberto Thomé, ${ }^{5}$ Paula Rahal, ${ }^{1}$ Sonia Maria Oliani, ${ }^{1}$ and Ana Elizabete Silva ${ }^{1}$ \\ ${ }^{1}$ Department of Biology, São Paulo State University (UNESP), Campus de São José do Rio Preto, Rua Cristóvão Colombo 2265, \\ 15054-000 São José do Rio Preto, SP, Brazil \\ ${ }^{2}$ Rio Preto Endoscopy Center, São José do Rio Preto, SP, Brazil \\ ${ }^{3}$ Endoscopy Service, Hospital de Base, São José do Rio Preto, SP, Brazil \\ ${ }^{4}$ Legal Medicine Department and Pathology Service, Hospital de Base, São José do Rio Preto, SP, Brazil \\ ${ }^{5}$ Institute of Anatomical Pathology and Cytopathology, São José do Rio Preto, SP, Brazil
}

Correspondence should be addressed to Sonia Maria Oliani; smoliani@ibilce.unesp.br and Ana Elizabete Silva; anabete@ibilce.unesp.br

Received 7 May 2012; Accepted 28 December 2012

Academic Editor: Eeva Moilanen

Copyright (C) 2013 Yvana Cristina Jorge et al. This is an open access article distributed under the Creative Commons Attribution License, which permits unrestricted use, distribution, and reproduction in any medium, provided the original work is properly cited.

Objective. The anti-inflammatory proteins annexin-A1 and galectin-1 have been associated with tumor progression. This scenario prompted us to investigate the relationship between the gene and protein expression of annexin-A1 (ANXA1/AnxA1) and galectin-1 (LGALS1/Gal-1) in an inflammatory gastric lesion as chronic gastritis (CG) and gastric adenocarcinoma (GA) and its association with $H$. pylori infection. Methods. We analyzed 40 samples of CG, 20 of GA, and 10 of normal mucosa (C) by the quantitative realtime PCR (qPCR) technique and the immunohistochemistry assay. Results. High ANXA1 mRNA expression levels were observed in $90 \%(36 / 40)$ of CG cases (mean relative quantification $\mathrm{RQ}=4.26 \pm 2.03)$ and in $80 \%(16 / 20)$ of $\mathrm{GA}$ cases (mean $\mathrm{RQ}=4.38 \pm 4.77)$. However, LGALS1 mRNA levels were high (mean RQ $=2.44 \pm 3.26)$ in $60 \%(12 / 20)$ of the GA cases, while low expression was found in $\mathrm{CG}$ (mean $\mathrm{RQ}=0.43 \pm 3.13 ; P<0.01$ ). Normal mucosa showed modest immunoreactivity in stroma but not in epithelium, while stroma and epithelium displayed an intense immunostaining in CG and GA for both proteins. Conclusion. These results have provided evidence that galectin-1 and mainly annexin-A1 are overexpressed in both gastritis and gastric cancer, suggesting a strong association of these proteins with chronic gastric inflammation and carcinogenesis.

\section{Introduction}

Chronic inflammation has been recognized as a process that can trigger cancer, due to the host immune response with local expression of cytokines, chemokines, adhesion molecules, and pro- and anti-inflammatory proteins that stimulate processes such as proliferation, survival, cell migration, and neovascularization. The strongest association between chronic inflammation and malignancy is observed in gastric cancer induced by Helicobacter pylori infection [1].
The inflammatory process resulting from $H$. pylori infection triggers a cascade of events initialized by chronic gastritis that evolves to gastric atrophy, intestinal metaplasia, dysplasia, and finally carcinoma [2]. This bacterium is present in $90 \%$ of all chronic gastritis patients [3] and in $77 \%$ of noncardia gastric cancers [4].

Both the intrinsic factors of the host and the bacterial virulence are associated with the development of gastric cancer induced by $H$. pylori. Among the bacterial genes, there is cagA, which is detected in about $63 \%$ of patients with gastric 
cancer [5]. The CagA protein is internalized by the host epithelial cells, disrupting the cell cycle and inducing cell invasion through the activation of matrix metalloproteases [6].

Bacterial lipopolysaccharides activate several cell processes, including expression of annexin-A1 (AnxA1) [7] and galectin-1 (Gal-1) [8], which are both anti-inflammatory proteins. During the inflammatory response, AnxA1 is translocated from the cell cytoplasm to the membrane, resulting in a decrease in the transmigration of inflammatory cells to the site of injury [9]. Furthermore, AnxA1 plays its antiinflammatory role by inhibiting the activities of phospholipase A2 and inducible nitric oxide synthase [10]. It is also associated with modifications of the cytoskeleton, transport of molecules, ion flux, differentiation and migration, cell growth, and apoptosis [11].

Galectin-1 (Gal-1), a member of a family of carbohydratebinding proteins, may act in the same manner as AnxA1 in the transmigration of inflammatory cells, being important also in T-cell apoptosis by binding to T-cell receptors, thus triggering the Faz/caspase cascade [12]. It also contributes to different events associated with carcinogenesis, including tumor transformation, cell cycle regulation, apoptosis, cell adhesion, migration, and inflammation $[13,14]$.

Nevertheless, there are only a few studies in the literature that evaluated the expression pattern of those antiinflammatory mediators in gastric mucosa, but their specific functions are unclear. While in gastric cell lines the Gal-1 protein expression increased $[15,16]$, in gastric adenocarcinoma was observed low expression in tumor cells [17]. In turn, AnxA1 was studied in gastric tissue with discrepant findings, such as increased expression during gastric mucosal damage healing [18], loss of expression in metastatic gastric cancers [19], higher expression in diffuse-type gastric cancer compared to the intestinal type [20], and decreased expression in gastric adenocarcinoma, but with positive staining in advanced stage and peritoneal dissemination [21].

Thus, further research in this field might improve our understanding of the possible role of those anti-inflammatory proteins in carcinogenesis, which is at present fairly limited and controversial. Moreover, such studies may lead to the possible identification of AnxA1 and Gal-1 as potential biomarkers in gastric cancer progression.

Therefore, the aim of this study was to investigate the relative expression levels of ANXA1 and LGALS1 mRNA by quantitative real-time PCR (qPCR) and the expression of both proteins by immunohistochemical assay in inflammatory gastric lesions such as chronic gastritis compared to gastric cancer. We also investigated a possible relationship between mRNA expression levels and $H$. pylori infection and its $\operatorname{cag} A$ virulence genotype in both lesions evaluated.

\section{Materials and Methods}

2.1. Subjects and Samples. Gastric biopsies were obtained from seventy (70) individuals submitted to endoscopy at the Endoscopy Service of the Hospital de Base and at Rio Preto Endoscopy Center, both in São José do Rio Preto, SP, Brazil. The histopathological data were supplied, respectively, by the
Legal Medicine Department and by the Pathology Service and the Institute of Anatomical Pathology and Cytopathology (IAPC), in the same city. For each individual, three (03) biopsy samples from the antrum region were collected for molecular studies and one for immunohistochemical analysis.

The gastric adenocarcinoma (GA) group comprised 20 individuals (14 male and 6 female; mean age $63.4 \pm 14$ years) with a histopathologically confirmed diagnosis of gastric adenocarcinoma [22]. Among the studied samples, 12 cases were diagnosed as intestinal-type adenocarcinoma (IGC) and 8 as diffuse-type adenocarcinoma (DGC). The chronic gastritis (CG) group was composed of 40 individuals (18 male and 22 female; mean age $52.5 \pm 15$ years) with a histopathologically confirmed diagnosis of chronic gastritis [23].

The biopsies for the control (C) group were obtained from 10 healthy individuals (7 male and 3 female; mean age $35 \pm 10.8$ years) with no dyspeptic gastric complaints and diagnosed as histopathologically normal gastric mucosa. Epidemiological data on the study population were collected using a standard interviewer-administered questionnaire, with questions about current and past occupation, smoking habits, alcohol intake, and family history of cancer. None of the 70 subjects were under antibiotic or anti-inflammatory treatment neither radiotherapy nor chemotherapy. About $60 \%$ of all patients in the GA group were smokers and $40 \%$ were drinkers, while all patients in the CG and $\mathrm{C}$ groups were nonsmokers and nondrinkers. Smokers were defined as individuals who consumed at least 100 cigarettes during their lifetime, and alcohol consumers were those who drank more than four times a week [24].

The Research Ethics Committee of the participating institution approved this research (CEP IBILCE/UNESP number 058/09), and written informed consent was obtained from all individuals studied.

2.2. Isolation of Total Nucleic Acids and Reverse-Transcription PCR (RT-PCR). Soon after collection, the biopsies were stored in RNA later solution (Applied Biosystems) at $-20^{\circ} \mathrm{C}$, to preserve their integrity until RNA extraction. The nucleic acid extraction was performed according to the protocol accompanying the reagent TRIzol (Invitrogen) that allows the simultaneous extraction of RNA and DNA. RNA and DNA concentrations were determined in a NanoDrop ND1000 spectrophotometer (Uniscience) by measuring absorbance at 260 and $280 \mathrm{~nm}$. DNA samples were stored at $-20^{\circ} \mathrm{C}$ and used for the molecular diagnosis of $H$. pylori.

Afterwards, reverse-transcription (RT) PCR was performed in an automated thermocycler, using $2.5 \mu \mathrm{g}$ of total RNA in the presence of $1.25 \mu \mathrm{L}$ of oligo-d(T)16 $(0.5 \mu \mathrm{g} / \mu \mathrm{L})$, $2.0 \mu \mathrm{L}$ of RNAse Inhibitor $(80 \mathrm{U} / \mu \mathrm{L})$, and a High Capacity cDNA Archive Kit (Applied Biosystems), in a total volume of $50 \mu \mathrm{L}$, according to the manufacturer's instructions. The reactions were carried out for 10 minutes at $25^{\circ} \mathrm{C}$, followed by 120 minutes at $37^{\circ} \mathrm{C}$. The integrity of all $\mathrm{cDNA}$ preparations was tested by a PCR assay of a 613 bp ACTB ( $\beta$-actin) gene fragment, used as control for abundant transcripts, whose primer sequences were F: $5^{\prime}$-GGCATCGTGATGGACTCC$3^{\prime}$ and R: $3^{\prime}$-GCTGGAAGGTGGACAGCG-5'. 
TABle 1: Primers sequences used in multiplex PCR to determine $H$. pylori infection and cagA genotype and in q-PCR assays.

\begin{tabular}{ll}
\hline Gene & Sequence $5^{\prime}-3^{\prime}$ \\
\hline \multirow{2}{*}{$H p X$} & F: CTGGAGARACTAAGYCCTCC \\
& R: GAGGAATACTCATTGCGAAGGCGA \\
\hline \multirow{2}{*}{ CYP1A1 } & F: CTCACCCCTGATGGTGCTAT \\
& R: TTTGGAAGTGCTCACAGCAG \\
\hline \multirow{2}{*}{ FagA } & F: ATGACTAACGAAACTATTGATC \\
& R: CAGGATTTTTGATCGCTTTATT \\
\hline \multirow{2}{*}{ LGALS1 } & F: GCAGGCCTGGTTTATTGAAA \\
& R: GCTGTGCATTGTTTCGCTTA \\
\hline \multirow{2}{*}{ FCTB } & F: GGACATCCTCCTGGACTCA \\
& R: GTTGAAGCGAGGGTTGAAGT \\
\hline
\end{tabular}

2.3. Molecular Diagnoses for $H$. pylori-cagA. To determine the presence of $H$. pylori infection, DNA samples were subjected to a multiplex PCR reaction containing primers for the bacterial gene $H p X$ [25] and for CYPIA1 (human housekeeping gene, which attests the integrity of the DNA).

In summary, we used $5.0 \mu \mathrm{L}$ of $10 \mathrm{X}$ buffer, $5.0 \mu \mathrm{L}$ of dNTPs (1.23 mmol/L, Invitrogen), $2.0 \mu \mathrm{L} \mathrm{MgCl}_{2}(25 \mathrm{mmol} / \mathrm{L}), 2.0 \mu \mathrm{L}$ of primers (10 nmol/ $\mu \mathrm{L}$, Invitrogen), $24.5 \mu \mathrm{L}$ of $\mathrm{dH}_{2} \mathrm{O}, 5.0 \mu \mathrm{L}$ of genomic DNA, and $0.5 \mu \mathrm{L}$ of Taq DNA Polymerase ( $5 \mathrm{U} / \mu \mathrm{L}$, Invitrogen). The material was processed in an automated thermocycler and was initially subjected to a temperature of $94^{\circ} \mathrm{C}$ for 5 minutes for denaturation. Subsequently, it was subjected to 40 amplification cycles at $94^{\circ} \mathrm{C}$ for 45 seconds, at $60^{\circ} \mathrm{C}$ for 30 seconds, and at $72^{\circ} \mathrm{C}$ for 90 seconds, followed by a final extension cycle of 7 minutes at $72^{\circ} \mathrm{C}$. The amplification products were visualized on $2.0 \%$ agarose gel stained with ethidium bromide. Fragments of $150 \mathrm{bp}$ and 226 bp corresponding to genes $C Y P 1 A 1$ and $H p X$, respectively, were observed.

The H. pylori-positive samples were then subjected to a second PCR run, to investigate the virulence genotype cagA of the bacterium [26]. The parameters used were the same as for the previous reaction, except the annealing temperature, which in this case was $52^{\circ} \mathrm{C}$. The product was visualized on $1.0 \%$ agarose gel stained with ethidium bromide, and a $232 \mathrm{bp}$ fragment was observed. Positive and negative controls were used in all experiments. The primer sequences are listed in Table 1.

2.4. Quantitative Analysis of the Relative Amount of ANXA1 and LGALS1 mRNA by Quantitative Real-Time PCR ( $q$ $P C R)$. The relative quantification q-PCR assay for ANXA1 and LGALS1 mRNA expression was performed in an ABI Prism 7300 Sequence Detector System (Applied Biosystems, Foster City, CA, USA), according to the instructions for the SYBR Green PCR Core Reagent (Applied Biosystems), using primers specific for genes ANXA1 and LGALS1 [27]. Gene $A C T B$ was used as endogenous control (reference gene) of the reaction, because it had shown the lowest variation compared to $\alpha$-tubulin and $\beta 2$-microglobulin genes in a previous study [28]. The primer sequences are presented in Table 1.

The expression levels of the ANXA1, LGALS1, and ACTB mRNA were tested in triplicate (cDNA from the same RT reaction, but in separated wells). Controls with no template cDNA were used for each assay (negative control). Samples of normal gastric mucosa were mixed to form a pool that was used as a calibrator (standard sample). The q-PCR assays were performed in a total volume of $50 \mu \mathrm{L}$, containing $10 \mu \mathrm{L}$ of SYBR Green Master Mix (Applied Biosystems), $25 \mathrm{ng}$ of cDNA, and $0.4 \mu \mathrm{M}$ of $A N X A 1$ and $0.5 \mu \mathrm{M} L G A L S 1$ primers.

After initial incubation at $50^{\circ} \mathrm{C}$ for $2 \mathrm{~min}$ to allow uracil$\mathrm{N}$-glycosylase (UNG) digestion and at $95^{\circ} \mathrm{C}$ for $10 \mathrm{~min}$ to activate the AmpliTaq Gold DNA polymerase (both provided by the Universal PCR Master Mix), the samples were amplified by subjecting them to 40 biphasic cycles of $95^{\circ} \mathrm{C}$ for $15 \mathrm{sec}$ and $60^{\circ} \mathrm{C}$ for $1 \mathrm{~min}$.

The fluorescence signal was measured in the extension phase of the PCR reaction, and a threshold value $\left(C_{T}\right)$ of fluorescence in the exponential part of the amplification curve was selected. The larger the quantities of the material at start, the lower the CT values. Relative quantification (RQ) of genes ANXA1 and LGALS1 was obtained as described by Pfaffl [29] and normalized with the $\beta$-actin control reference gene and normal gastric mucosa. The transcript levels were considered to be upregulated if RQ $>2.0$.

\subsection{Immunohistochemistry. Deparaffinized sections $(4 \mu \mathrm{m})$} were incubated in citrate buffer, $\mathrm{pH} 6.0$, at $96^{\circ} \mathrm{C}$ for 30 minutes, washed with distilled water, incubated with $3 \%$ hydrogen peroxide in methanol (30 minutes), and washed in phosphate-buffered saline (PBS, $\mathrm{pH}$ 7.4). The primary antibodies rabbit polyclonal anti-Gal-1 and rabbit polyclonal anti-ANXA1 (Zymed Laboratories, Cambridge, UK) were diluted to $1: 500$ or $1: 2000$, respectively, in $1 \%$ bovine serum albumin (BSA) and applied overnight at $4^{\circ} \mathrm{C}$. As negative controls, some sections were incubated with $1 \%$ BSA without any primary antibody. Fragments were then washed in PBS, incubated with the universal LSAB kit/HRP secondary antibody (Dako, USA) according to the manufacturer's protocol, washed in PBS, and developed with $3,3^{\prime}$-diaminobenzidine in chromogen solution (Dako, USA). The sections were washed thoroughly in distilled water, counterstained with hematoxylin and mounted on glass slides. Densitometric analysis for AnxA1 and Gal-1 immunostaining was performed using an arbitrary scale from 0 to 255 with the AxioVision software on a Zeiss-Axioskop II light microscope, and the data were expressed as mean $\pm \mathrm{SE}$.

2.6. Statistical Analysis. Fisher's exact test was used to determine if there were significant differences between groups regarding the presence of bacteria and the cagA genotype, the histological type of tumor, and the gender. The data obtained from mRNA quantification were expressed as mean \pm SD. To assess differences in the mRNA relative expression levels between the groups, we used the nonparametric MannWhitney test. To evaluate the association between gene expression and the presence of the bacterium and cagA 
TABLE 2: Distribution of infection by H. pylori and cagA strains into chronic gastritis (CG) and gastric adenocarcinoma (GA) groups.

\begin{tabular}{|c|c|c|}
\hline Status & $\begin{array}{c}\text { CG } \\
N(\%)\end{array}$ & $\begin{array}{c}\text { GA } \\
N(\%)\end{array}$ \\
\hline \multicolumn{3}{|l|}{ H. pylori } \\
\hline Positive & $16(40)$ & $11(55)$ \\
\hline Negative & $24(60)$ & $9(45)$ \\
\hline Total & $40(100)$ & $20(100)$ \\
\hline$P$ & \multicolumn{2}{|c|}{0.29} \\
\hline \multicolumn{3}{|c|}{ Genotype cagA } \\
\hline Positive & $10(62.5)$ & $3(27.3)$ \\
\hline Negative & $6(37.5)$ & $8(72.7)$ \\
\hline Total & $16(100)$ & $11(100)$ \\
\hline$P$ & \multicolumn{2}{|c|}{0.12} \\
\hline
\end{tabular}

genotype, histological type of tumor, gender, smoking, and drinking, we used the nonparametric $t$-test with Welch's correction. The value of protein expression was expressed as mean \pm SE. The mean densitometry analysis results obtained for proteins AnxA1 and Gal-1 were compared by ANOVA, followed-if significant-by the Bonferroni test. These analyses were performed using the GraphPad InStat and GraphPad Prism 4 software. The value was considered significant if $P<$ 0.05 .

\section{Results}

3.1. Molecular Diagnoses for $H$. pylori-cagA. The frequencies of cases with positive molecular diagnosis for $H$. pylori and genotype cagA in groups $C G$ and GA are presented in Table 2. All 10 samples of normal mucosa were confirmed by molecular testing as $H$. pylori negative.

Out of a total of 60 samples from the case groups, $45 \%$ were $H$. pylori positive: $40 \%(16 / 40)$ in the CG group and $55 \%(11 / 20)$ in the GA group, with no significant difference between the groups $(P=0.29)$. Regarding the genotype cag $A$, $48 \%$ of $H$. pylori-positive samples were cagA positive: $62.5 \%$ $(10 / 16)$ in the CG and $27.3 \%$ (3/11) in the GA group. Again, there was no significant difference between the groups $(P=$ $0.12)$.

3.2. Relative Gene Expression Analysis. The relative expression levels of ANXA1 mRNA, after normalization with the $A C T B$ reference gene and comparison with the normal mucosa, were increased in $90 \%(36 / 40)$ of the CG cases (mean $\mathrm{RQ}=4.26 \pm 2.03)$ and in $80 \%(16 / 20)$ of the GA cases (mean $\mathrm{RQ}=4.38 \pm 4.77)$, so there was no statistically significant difference between the groups $(P=0.33)$. For LGALS1, the mRNA relative expression values found were lower; only the GA group showed overexpression in 60\% (12/20) of the cases (mean RQ $=2.44 \pm 3.26)$. The $\mathrm{CG}$ group showed constitutive expression (mean RQ $=0.43 \pm 3.13$, with only $7.5 \%(3 / 40)$ of the cases presenting increased expression. Thus, the mean level of LGALS1 mRNA expression was significantly higher in the GA than in the CG group $(P<0.01)$ (Table 3 and Figure 1).

In another analysis, we investigated the GA group for a possible association between ANXA1 and LGALS1 mRNA expression and risk factors such drinking, smoking, and histological type of gastric cancer (Table 4), but no association was observed. In addition, comparing the variables, gender, H. pylori infection, and cagA+ genotype, in the CG and the GA groups (Table 5), a significant difference was found in the GA group for the gender and the mean level of ANXA1 expression $(P=0.04)$, due to a 2 times greater expression of this gene in the females than in the males of this group. Likewise, the cagA+ genotype also showed an association with the ANXA1 expression level in the GA group, due to a higher mRNA expression in the cagA-positive compared to the cag $A$-negative cases (mean RQ 6.40 versus $2.77, P<0.01$ ). None of the other investigated factors appears to be associated with the levels of ANXA1 and LGALS1 mRNA.

\subsection{Protein Expression Measured by Immunohistochemistry} Assay. Protein expression was evaluated in normal mucosa, CG, intestinal (IGC), and diffuse- (DGC-) type gastric cancer. Modest expression of AnxA1 and Gal-1 was observed in the stroma of normal mucosa, while the epithelium did not show any expression of these proteins (Figures 2(a) and 3(a), resp.). However, in the inflammatory process of CG mucosa, intense immunostaining of AnxA1 and Gal-1 was seen in the basal portion of the epithelium (Figures 2(b) and 3(b), resp.). Positive immunostaining for AnxA1 and Gal-1 was also observed in DGC (Figures 2(c) and 3(c), resp.) and IGC (Figures 2(d) and 3(d), resp.) tumor cells. In some areas of gastric cancer samples, it was possible to identify epithelial cells showing AnxA1 and Gal-1 expression.

The mean optical densitometry values of AnxA1 and Gal-1 expression are presented in Figures 2(e) and 3(e), respectively. The AnxA1 mean density was 90.79 for normal mucosa (C group), while for CG and GA, it was, respectively, 168.57 and 190.20. Thus, a significant difference was found comparing the normal mucosa with the CG and GA groups $(P<0.01$ for both). The mean density of the Gal-1 protein was lower in all three groups $(86.52,136.97$, and 146.30 in C, CG, and GA, resp.), showing a statistically significant difference between the normal mucosa and the CG and GA groups $(P<0.01$ for both).

In another densitometry analysis to determine the cytoplasmic and nuclear immunoreactivity of AnxA1 separately in all groups, although observed nuclear immunostaining mainly in gastric cancer, the data obtained in our results did not show a statistically significant difference between normal mucosa and CG $(P=0.19)$ and normal mucosa and GA $(P=0.18)$ (data not shown).

\section{Discussion}

In the present study, we evaluated AnxA1 and Gal-1 antiinflammatory proteins and mRNA expression in a group of precursor lesions such as chronic gastritis compared to gastric cancer and their association with risk factors. Among the risk 
TABLE 3: Comparison of ANXA1 and LGALS1 mRNA relative expression levels between the chronic gastritis (CG) and the gastric adenocarcinoma (GA) groups.

\begin{tabular}{|c|c|c|c|c|}
\hline \multirow{2}{*}{ Variable } & \multicolumn{2}{|c|}{$A N X A 1$} & \multicolumn{2}{|c|}{$L G A L S 1$} \\
\hline & CG & GA & CG & GA \\
\hline Relative expression (mean \pm SD) & $4.26 \pm 2.03$ & $4.38 \pm 4.77$ & $0.43 \pm 3.13$ & $2.44 \pm 3.26$ \\
\hline Minimum & -2.97 & -7.88 & -10.78 & -6.95 \\
\hline Maximum & 8.90 & 9.29 & 10.91 & 9.28 \\
\hline$P$ & \multicolumn{2}{|c|}{0.33} & \multicolumn{2}{|c|}{$<0.01^{*}$} \\
\hline
\end{tabular}

${ }^{*}$ Significant difference.

TABLE 4: Relative expression of ANXA1 and LGALS1 mRNA in the gastric adenocarcinoma group related to drinking, smoking, and histological type of cancer.

\begin{tabular}{lcc}
\hline Variable & ANXA1 & LGALS1 \\
\hline Drinking & & \\
$\quad$ Yes & $8(40 \%)$ & $8(40 \%)$ \\
$\quad($ mean \pm SD) & $2.29 \pm 5.76$ & $1.74 \pm 1.49$ \\
No & $12(60 \%)$ & $12(60 \%)$ \\
$($ mean \pm SD) & $5.98 \pm 2.61$ & $2.82 \pm 3.91$ \\
$P$ & 0.15 & 0.39 \\
Smoking & & \\
Yes & $12(60 \%)$ & $12(60 \%)$ \\
$($ mean \pm SD) & $4.01 \pm 5.54$ & $2.44 \pm 2.18$ \\
No & $8(40 \%)$ & $8(40 \%)$ \\
$($ mean \pm SD) & $4.20 \pm 4.17$ & $2.45 \pm 4.21$ \\
$P$ & 0.93 & 0.99 \\
Histology & & $12(60 \%)$ \\
Intestinal & $12(60 \%)$ & $3.60 \pm 2.79$ \\
$($ mean \pm SD) & $5.82 \pm 2.89$ & $8(40 \%)$ \\
Diffuse & $8(40 \%)$ & $0.71 \pm 3.32$ \\
$($ mean \pm SD) & $1.55 \pm 6.02$ & 0.06 \\
$P$ & 0.09 & \\
\hline
\end{tabular}

factors, we investigated the presence of $H$. pylori in both lesions and its virulence genotype cagA, since this bacterium often triggers the progression of the gastric carcinogenesis cascade. To the best of our knowledge, this is the first study that has evaluated the expression of AnxA1 and Gal-1 in chronic gastritis.

We have found a high relative expression of ANXA1 mRNA already in the CG inflammatory process, in which $90 \%$ of cases showed an increased expression level (mean RQ $=4.26$ ), which became 3 to 8 times higher after normalization with the $A C T B$ reference gene and comparison with normal mucosa. Similarly, in the GA group, $80 \%$ of cases presented upregulated expression levels, which were 3 to 9 times higher (mean RQ $=4.38$ ) than that in normal mucosa. For LGALS1, our study showed a slightly increased relative expression only in $60 \%$ of the GA cases (mean RQ $=2.44$ ), with an increase of 2 to 7 times, but in chronic gastritis the mean value was low (mean RQ $=0.43$ ). In general, the immunohistochemical analysis confirmed the results of mRNA expression by qPCR, although in CG the relative expression levels of LGALS1 mRNA was not equivalently increased as protein expression.
Studies on the expression of ANXA1 mRNA in neoplastic processes are still limited and the results are conflicting. For example, loss of expression was found in squamous cell carcinoma of the esophagus [30], prostatic adenocarcinoma [31], sinonasal adenocarcinoma [32], larynx [33], and breast cancer [34]. On the other hand, overexpression has been reported in colorectal adenocarcinoma [35], urothelial carcinoma [36], lung adenocarcinoma [37], and oral cancers [38], thus suggesting that changes in the expression levels of ANXA1 may be related to the tissue or tumor type.

Martin et al. [18] reported that normal gastric mucosa shows weak expression of the protein AnxA1, while in the ulcer healing process the expression was increased, promoting the reduction of the ulcer. In contrast, Yu et al. [19] observed overexpression of both gene and protein in normal mucosa but loss of expression in $64 \%$ of primary gastric tumors, mainly correlated with advanced stage and metastasis. More recently, Zhu et al. [21] observed that AnxA1 protein is expressed in both gastric adenocarcinoma (45\%) and normal tissues (69\%), but with different subcellular distribution. Similar results were reported by Cheng et al. [39] that observed high AnxA expression, both mRNA and protein, associated with metastasis, invasion, and poor survival in gastric cancer patients. The authors also proposed a new mechanism of how AnxA1 regulates the gastric cancer cell invasion through activation FPR/ERK/ITGB1BP1 pathway.

In the present study, the immunohistochemical analysis for AnxA1 showed modest immunostaining in stromal cells of normal mucosa and intense expression in stroma and epithelium of both CG and GA, thus confirming the results of the mRNA expression analysis. The assay used in this study did not allow a clear differentiation of the cellular localization of the protein, although positive immunostaining was observed in the cytoplasm of epithelial cells and the nucleus of cancer cells, with lower intensity and frequency in chronic gastritis. However, when the densitometry analysis to determine cytoplasmic and nuclear immunoreactivity of AnxA1 separately was performed, the data obtained did not show a statistically significant difference among normal mucosa, chronic gastritis, and gastric adenocarcinoma. Although, there are some reports that show translocation of AnxA1 during carcinogenesis, as Alves et al. [40] that showed $87.5 \%$ positivity for AnxA1 in larynx tumors and increased immunoreactivity in the membrane compared to the cytoplasm and the nucleus. However, compared to the normal tissue, the nuclear and cytoplasmic expression was lower. In esophageal carcinoma, Liu et al. [41] found AnxA1 
TABLE 5: Relative expression of ANXA1 and LGALS1 mRNA in chronic gastritis (CG) and gastric adenocarcinoma (GA) groups according to gender, infection by $H$. pylori, and presence of $\operatorname{cag} A+$ genotype.

\begin{tabular}{|c|c|c|c|c|}
\hline \multirow{2}{*}{ Variable } & \multicolumn{2}{|c|}{$A N X A 1$} & \multicolumn{2}{|c|}{$L G A L S 1$} \\
\hline & CG & GA & CG & GA \\
\hline \multicolumn{5}{|l|}{ Gender } \\
\hline Female & $22(55 \%)$ & $6(30 \%)$ & $22(55 \%)$ & $6(30 \%)$ \\
\hline$($ mean $\pm S D)$ & $4.40 \pm 1.80$ & $6.67 \pm 2.00$ & $0.29 \pm 3.55$ & $4.81 \pm 3.26$ \\
\hline Male & $28(45 \%)$ & $14(70 \%)$ & $28(45 \%)$ & $14(70 \%)$ \\
\hline$($ mean $\pm S D)$ & $4.08 \pm 2.32$ & $3.25 \pm 5.16$ & $0.60 \pm 2.61$ & $1.66 \pm 2.96$ \\
\hline$P$ & 0.63 & $0.04^{*}$ & 0.75 & 0.10 \\
\hline \multicolumn{5}{|l|}{ H. pylori } \\
\hline Positive & $16(40 \%)$ & 11 (55\%) & $16(40 \%)$ & $11(55 \%)$ \\
\hline$($ mean $\pm S D)$ & $4.04 \pm 2.59$ & $3.91 \pm 5.48$ & $-0.05 \pm 3.97$ & $3.33 \pm 3.16$ \\
\hline Negative & $24(60 \%)$ & $9(45 \%)$ & $24(60 \%)$ & $9(45 \%)$ \\
\hline$($ mean $\pm S D)$ & $4.40 \pm 1.60$ & $4.35 \pm 4.05$ & $0.75 \pm 2.46$ & $1.36 \pm 3.23$ \\
\hline$P$ & 0.47 & 0.61 & 0.24 & 0.73 \\
\hline \multicolumn{5}{|l|}{ Genotype cagA } \\
\hline Positive & $10(62.5 \%)$ & $3(27.3 \%)$ & $10(62.5 \%)$ & $3(27.3 \%)$ \\
\hline$($ mean $\pm S D)$ & $2.91 \pm 2.74$ & $6.40 \pm 3.00$ & $-1.57 \pm 3.62$ & $2.58 \pm 1.26$ \\
\hline Negative & $6(37.5 \%)$ & $8(72.7 \%)$ & $6(37.5)$ & $8(72.7 \%)$ \\
\hline$($ mean $\pm S D)$ & $5.49 \pm 1.56$ & $2.77 \pm 6.52$ & $1.89 \pm 3.74$ & $2.80 \pm 3.10$ \\
\hline$P$ & 0.14 & $<0.01^{*}$ & 0.09 & 0.51 \\
\hline
\end{tabular}

${ }^{*}$ Significant difference.

translocation from the cellular to the nuclear membrane. While in gastric adenocarcinoma AnxAl showed positive nuclear staining correlated with advanced disease stage and peritoneal dissemination but in normal tissues was predominantly localized in the cytoplasm [21]. In addition, weak nuclear staining also occasionally occurred in sporadic cells of gastric tumors (14/118 cases) evaluated by Cheng et al. [39]. But, in general, the AnxA1 immunostaining was mainly cytoplasmatic in the epithelial cells.

Changes in the expression pattern of AnxAl must be related with factors that influence its translocation and export, such as the cellular concentration of calcium, considering that, when the intracellular calcium level is increased, AnxA1 is translocated to membranes [42]. Furthermore, it is reported that protein phosphorylation is also required for this process [20]. In tumor cells, calcium and other factors may be altered, resulting in an abnormal location of AnxA1. However, this relationship needs to be better understood and may be the connection between inflammation, signal transduction, differentiation, and cellular transport in cancer [40].

To date, Gal-1 is involved in various important aspects of carcinogenesis, so mRNA and protein expressions have been examined in several types of cancer. Overexpression has been reported in colorectal cancer [43], Hodgkin's lymphoma [44], squamous cell carcinomas of the larynx, and carcinomas of the hypopharynx [45]. Conversely, there is also a report of low expression, as in chronic inflammation of nasal polyposis [27].

Two research groups evaluated the expression of Gal1 in gastric cell lines and both agreed that this protein is overexpressed in tumor cells. Chen et al. [16] showed higher expression of the protein in TMC-1 compared to SC-M1 cells, proposing Gal-1 as a biomarker for metastasis. Lim et al. [15] investigated AGS cells infected by $H$. pylori and observed high expression levels of Gal-1 in this cell type. Recently, Estofolete et al. [46] observed by immunostaining that both Gal-1 and -3 were highly expressed in an experimental model of $\mathrm{N}$-methyl-N ${ }^{\prime}$-nitro-N-nitrosoguanidine- (MNNG-) induced gastric carcinogenesis.

The immunohistochemistry assay performed showed modest staining for Gal-1 in the stroma of normal mucosa, while in CG and GA the staining was stronger in stroma and epithelium. In contrary, the LGALS1 mRNA levels were lower in the CG group in comparison with the GA group. Several studies have shown lack of correlation between RNA expression and protein expression profiles using different methodologies. Some authors state that in fact the use of mRNA expression patterns is insufficient for understanding the expression of protein products, as additional posttranscriptional mechanisms, including protein translation, posttranslational modification, and degradation, may influence the level of a protein present in a given cell or tissue [47-50].

The comparison between the CG and GA groups regarding ANXA1 and LGALS1 mRNA levels and risk factors did not show any association with the LGALS1 mRNA levels. However, a positive association was observed between overexpression of $A N X A 1$ and female gender in the GA group, since in women the mRNA expression was twice as high as in men (mean $\mathrm{RQ}=6.67$ versus 3.25), and the H. pylori-cagA+ infection showed an mRNA mean level approximately twice higher in patients infected by cagA + strains (mean $R Q=6.40$ versus mean $R Q=2.77$ ). Despite the relevance of the study, it should be considered some limitations due to the reduced number of cases in the subgroup stratification, which should be interpreted with cautions. It would need confirmation in further studies with larger population. 


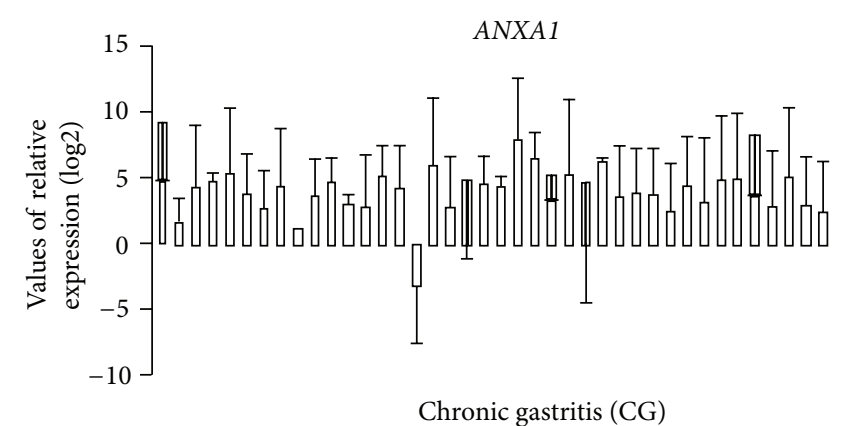

(a)

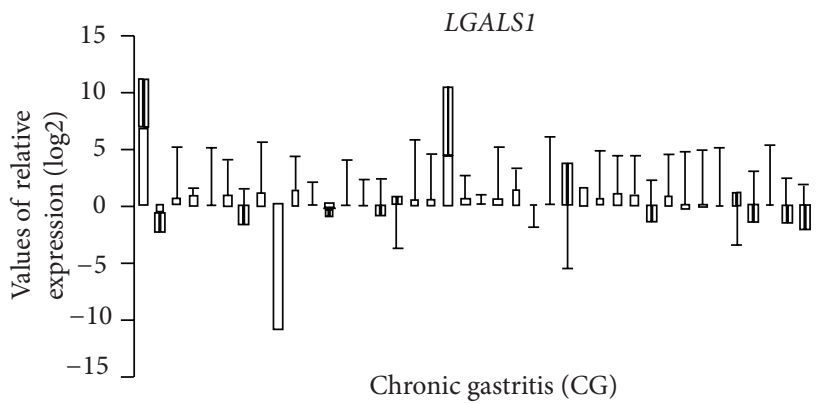

(c)

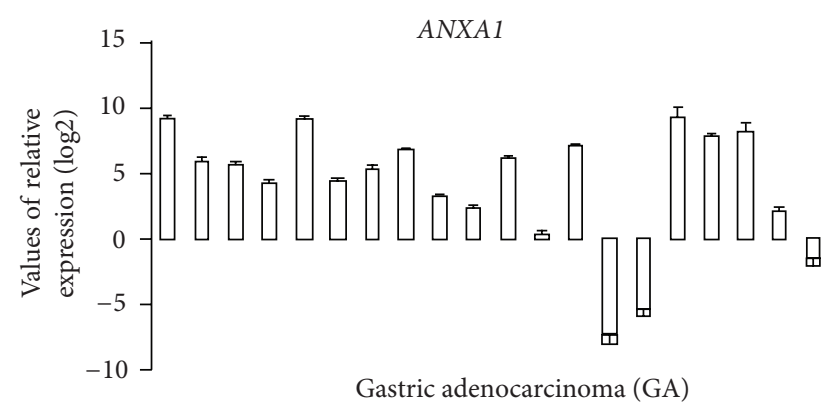

(b)

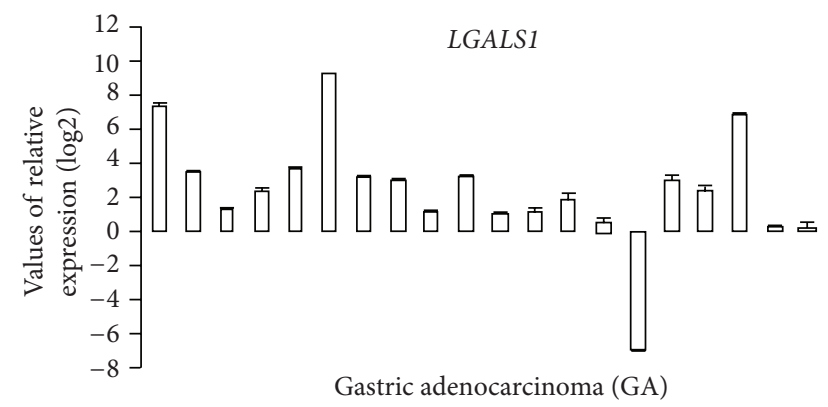

(d)

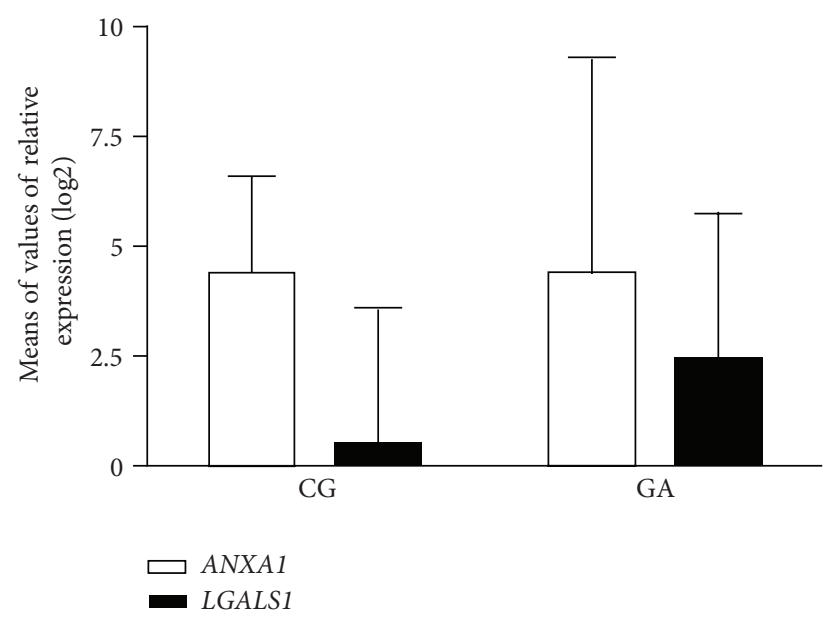

(e)

FiguRE 1: Values of relative gene expression $(\log 2)$ of $A N X A 1(\mathrm{a}, \mathrm{b})$ and $\operatorname{LGALS1}(\mathrm{c}, \mathrm{d})$ and means of values of relative gene expression (e) in the chronic gastritis (CG) and gastric adenocarcinoma (GA) groups.

It is well known that there is sexual dimorphism in the immune and inflammatory responses in humans. Women produce more vigorous cellular and humoral reactions, are more resistant to certain infections, and suffer a higher incidence of autoimmune diseases than males [51]. It is possible that hormonal differences may explain part of this dimorphism. It has also been suggested that the ANXA1 expression may differ in several types of cancer due to hormonal influence [52].

Ang et al. [52] conducted a very elegant study on the influence of AnxA1 in MCF-7 breast cancer cells, in which they showed that $17 \beta$-estradiol (active metabolite of estrogen) regulates ANXA1 expression. Moreover, $17 \beta$-estradiol was shown to activate cyclic-AMP- (cAMP-) responsive element (CRE) binding (CREB) proteins to induce a transcriptional activity. The promoter region of ANXA1 was examined and found to contain a similar, near identical, 8-nucleotide sequence (TGATGTCA) to the CRE consensus sequence (TGACGTCA). So, estrogen could also promote the transcription of ANXA1. Yet, those authors proposed another theory to explain the connection between estrogen and AnxA1 levels. Elevated $17 \beta$-estradiol activates the ERK1/2 pathway, increasing cell proliferation, and this serves as a sign to stimulate ANXA1 transcription in order to reduce the proliferative state. Then, AnxA1 upregulates p21, which has antiproliferative properties, and reduces the proliferation 


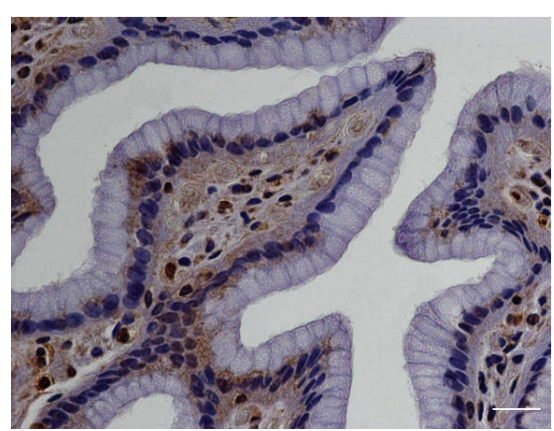

(a)

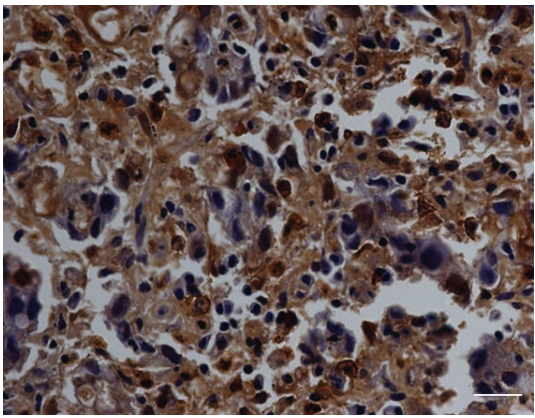

(c)

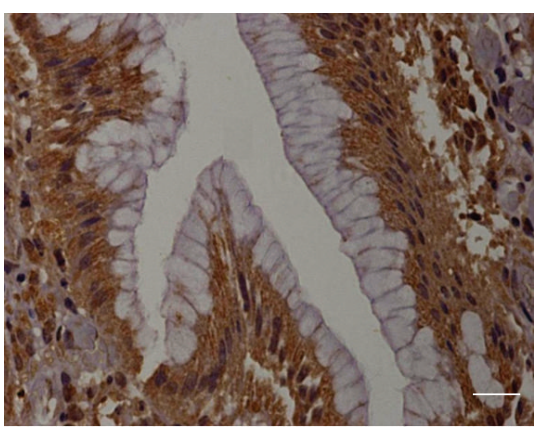

(b)

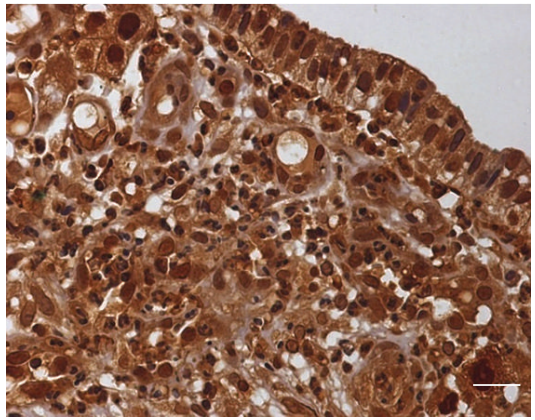

(d)

AnxA1

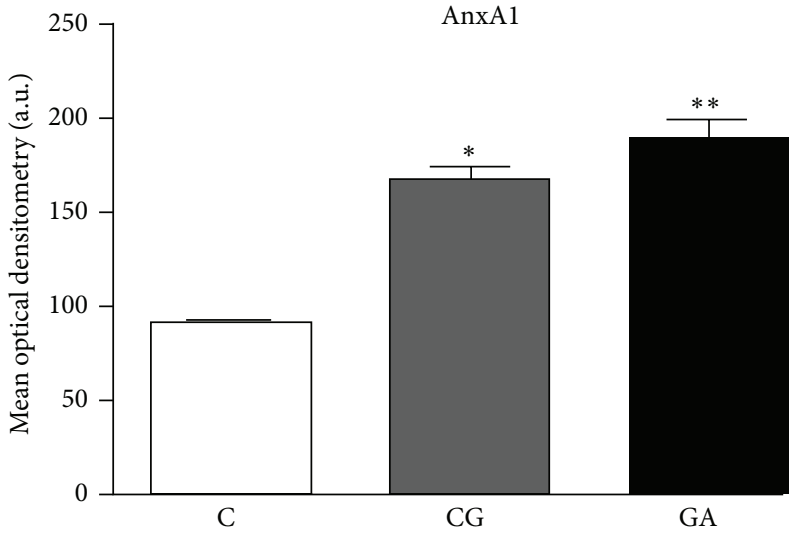

(e)

FIGURE 2: Endogenous annexin-A1 (ANXA1) expression in the gastric mucosa. Immunoreactivity of ANXA1 in sections of gastric mucosa tissue by rabbit polyclonal antibody ANXA1. (a) Histological analysis showing modest immunoreactivity in stroma and negative for epithelial cells in normal mucosa. Note the immunopositivity in basal portion of epithelial in (b) chronic gastritis and intense stromal-epithelial immunostaining in (c) diffuse-type adenocarcinoma and (d) intestinal-type adenocarcinoma. Hematoxylin counterstain. Bar: $20 \mu \mathrm{m}$. (e) Densitometry analyses on the gastric mucosa tissues immunostained for AnxAl in normal mucosa (C), chronic gastritis (CG), and gastric adenocarcinoma (GA) groups. Comparison between the $\mathrm{C}$ group and the $\mathrm{CG}\left({ }^{*}\right)$ and $\mathrm{GA}\left({ }^{* *}\right)$ groups was made by the ANOVA test, with $P<0.01$.

caused by the activation of ERK1/2 by estrogen. However, in our study, in the GA group the mean age of women was elevated (67.4 \pm 18.4 years), which characterizes the postmenopausal phase that have decreased estrogen levels, thus not justifying the relation between increased expression of $A N X A 1$ and estrogen. Therefore, further studies are needed in order to clarify this issue.

The relationship between the presence of virulence factor CagA and gastric carcinogenesis is well documented. Western populations infected with CagA-positive strains generally have an accentuated inflammatory response, with increased risk of developing peptic ulcer and stomach cancer [53]. The phosphorylation of the CagA protein activates SHP2 (protein tyrosine phosphatase), which then inhibits the FAK (focal adhesion kinase), an enzyme that modulates adhesion, migration, and cell survival [4]. Consequently, the decline in the activity of FAK triggers a rearrangement of the cytoskeleton known as the hummingbird phenotype, 


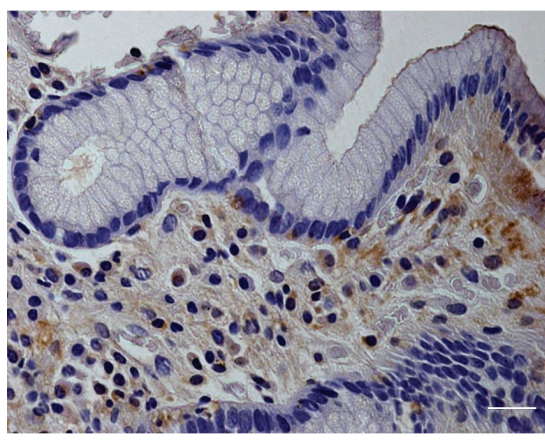

(a)

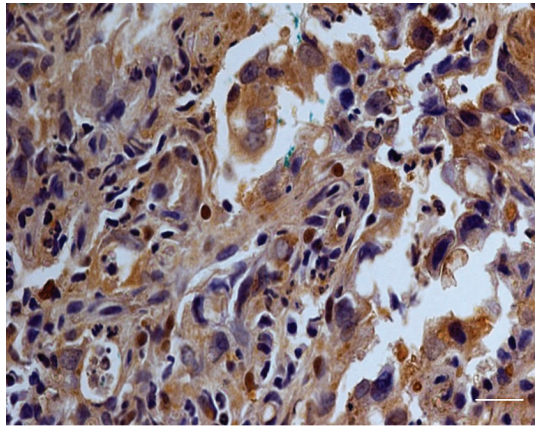

(c)

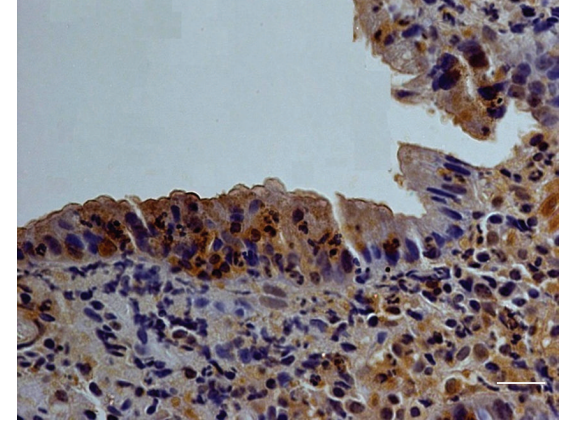

(b)

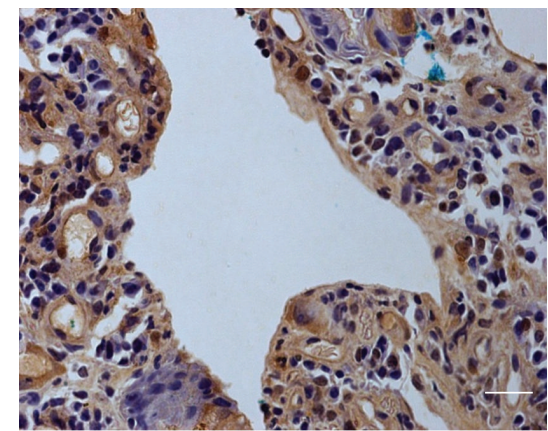

(d)

Gal-1

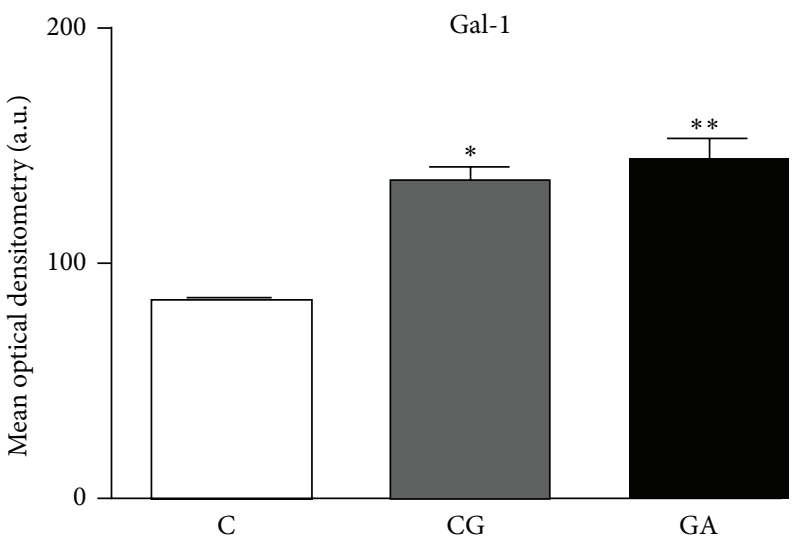

(e)

FIgURE 3: Endogenous galectin 1 (Gal-1) expression in the gastric mucosa. Immunoreactivity of Gal-1 in sections of gastric mucosa tissue by rabbit polyclonal anti-Gal-1. (a) Negative immunostaining in epithelium and modest positivity in stroma in normal mucosa. Immunopositivity in basal portion of epithelial in chronic gastritis (b) and, intense stromal-epithelial immunostaining in diffuse-type adenocarcinoma (c) and intestinal-type adenocarcinoma (d). Hematoxylin counterstain. Bar: $20 \mu \mathrm{m}$. (e) Densitometry analyses on the gastric mucosa tissues immunostained for Gal-1 in normal mucosa (C), chronic gastritis (CG), and gastric adenocarcinoma (GA) groups. Comparison between the $\mathrm{C}$ group and the $\mathrm{CG}\left({ }^{*}\right)$ and GA $\left({ }^{* *}\right)$ groups was made by the ANOVA test, with $P<0.01$.

characterized by elongation and spreading of host cells [54]. Furthermore, CagA participates in cell signaling by activating the PIK3CA and KRAS pathways [1], ERK (MAPK) [55, 56], and MEK/ERK and JAK1 signaling pathway in gastric cancer cells [57]. To our knowledge, there are no reports about the relationship to the CagA virulence factor and the expression of ANXA1 and Gal-1 anti-inflammatory proteins. However, Lin et al. [58] observed overexpression of AnxA4 in tumor cells of patients infected with $H$. pylori and in gastric cancer SCM-1 cells after $H$. pylori infection. Recently, Lin et al. [59] observed that infection by $H$. pylori induced a change in AnxAl and AnxA4 localization, causing a translocation from the cytoplasm to the plasma membrane, probably for epithelial cell membrane repair in the consequence of $H$. pylorigenerated membrane disruptions. So, due to the action of CagA bacterial protein in different cell signaling pathways, it is possible that it may also contribute to activation of ANXA1 expression mainly, considering that this protein plays a key role as intracellular $\mathrm{Ca}^{2+}$ flux, modifications of the cytoskeleton, differentiation and migration, cell growth, and apoptosis. 


\section{Conclusions}

In conclusion, this study showed overexpression of both ANXA1 mRNA and protein already in a precursor lesion such as $C G$, similar to GA, in which higher expression levels were observed in $H$. pylori-cagA+ cases, suggesting upregulation of this gene in early stages of gastric carcinogenesis. In turn, LGALS1 (mRNA or protein) was slightly overexpressed in both lesions, indicating also its participation in gastric carcinogenesis. However, as in several types of cancers the role of these proteins is not yet fully understood, further investigations are needed to help clarify the molecular mechanisms by which they act in this kind of lesion.

\section{Acknowledgment}

This study was supported by the Brazilian agencies FAPESP, CNPq, and CAPES.

\section{References}

[1] T. Chiba, H. Marusawa, and T. Ushijima, "Inflammation-associated cancer development in digestive organs: mechanisms and roles for genetic and epigenetic modulation," Gastroenterology, vol. 143, pp. 550-563, 2012.

[2] P. Correa, "A human model of gastric carcinogenesis," Cancer Research, vol. 48, no. 13, pp. 3554-3560, 1988.

[3] T. Robbins and R. S. Cotran, "Stomach," in Pathologic Bases of Diseases, pp. 787-801, Saunders, Philadelphia, Pa, USA, 6th edition, 2005.

[4] L. T. Nguyen, T. Uchida, K. Murakami, T. Fujioka, and M. Moriyama, "Helicobacter pylori virulence and the diversity of gastric cancer in Asia," Journal of Medical Microbiology, vol. 57, no. 12, pp. 1445-1453, 2008.

[5] J. Q. Huang, G. F. Zheng, K. Sumanac, E. J. Irvine, and R. H. Hunt, "Meta-analysis of the relationship between cagA seropositivity and gastric cancer," Gastroenterology, vol. 125, no. 6, pp. 1636-1644, 2003.

[6] H. Isomoto, Y. Nishi, K. Ohnita et al., "The relationship between plasma and gastric ghrelin levels and strain diversity in Helicobacter pylori virulence," American Journal of Gastroenterology, vol. 100, no. 6, pp. 1425-1427, 2005.

[7] C. D. John, F. N. Gavins, N. A. Buss, P. O. Cover, and J. C. Buckingham, "Annexin Al and the formyl peptide receptor family: neuroendocrine and metabolic aspects," Current Opinion in Pharmacology, vol. 8, no. 6, pp. 765-776, 2008.

[8] J. Almkvist and A. Karlsson, "Galectins as inflammatory mediators," Glycoconjugate Journal, vol. 19, no. 7-9, pp. 575-581, 2002.

[9] T. S. Gastardelo, A. S. Damazo, J. Dalli, R. J. Flower, M. Perretti, and S. M. Oliani, "Functional and ultrastructural analysis of annexin A1 and its receptor in extravasating neutrophils during acute inflammation," American Journal of Pathology, vol. 174, no. 1, pp. 177-183, 2009.

[10] L. Parente and E. Solito, "Annexin 1: more than an anti-phospholipase protein," Inflammation Research, vol. 53, no. 4, pp. 125-132, 2004.

[11] V. Gerke, C. E. Creutz, and S. E. Moss, "Annexins: linking $\mathrm{Ca}^{2+}$ signalling to membrane dynamics," Nature Reviews Molecular Cell Biology, vol. 6, no. 6, pp. 449-461, 2005.

[12] P. Matarrese, A. Tinari, E. Mormone et al., "Galectin-1 sensitizes resting human T lymphocytes to Fas (CD95)-mediated cell death via mitochondrial hyperpolarization, budding, and fission," Journal of Biological Chemistry, vol. 280, no. 8, pp. 69696985, 2005.

[13] G. A. Rabinovich, "Galectin-1 as a potential cancer target," British Journal of Cancer, vol. 92, no. 7, pp. 1188-1192, 2005.

[14] C. D. Gil, D. Cooper, G. Rosignoli, M. Perretti, and S. M. Oliani, "Inflammation-induced modulation of cellular galectin-1 and -3 expression in a model of rat peritonitis," Inflammation Research, vol. 55, no. 3, pp. 99-107, 2006.

[15] J. W. Lim, H. Kim, and K. H. Kim, "Cell adhesion-related gene expression by Helicobacter pylori in gastric epithelial AGS cells," International Journal of Biochemistry and Cell Biology, vol. 35, no. 8, pp. 1284-1296, 2003.

[16] Y. R. Chen, H. F. Juan, H. C. Huang et al., "Quantitative proteomic and genomic profiling reveals metastasis-related protein expression patterns in gastric cancer cells," Journal of Proteome Research, vol. 5, no. 10, pp. 2727-2742, 2006.

[17] S. Bektas, B. Bahadir, B. H. Ucan, and S. O. Ozdamar, "CD24 and galectin-1 expressions in gastric adenocarcinoma and clinicopathologic significance," Pathology and Oncology Research, vol. 16, no. 4, pp. 569-577, 2010.

[18] G. R. Martin, M. Perretti, R. J. Flower, and J. L. Wallace, "Annexin-1 modulates repair of gastric mucosal injury," American Journal of Physiology, vol. 294, no. 3, pp. G764-G769, 2008.

[19] G. Yu, J. Wang, Y. Chen et al., "Tissue microarray analysis reveals strong clinical evidence for a close association between loss of annexin A1 expression and nodal metastasis in gastric cancer," Clinical and Experimental Metastasis, vol. 25, no. 7, pp. 695-702, 2008.

[20] C. M. Wu, Y. S. Lee, T. H. Wang et al., "Identification of differential gene expression between intestinal and diffuse gastric cancer using cDNA microarray," Oncology Reports, vol. 15, no. 1, pp. 57-64, 2006.

[21] F. Zhu, C. Xu, Z. Jiang et al., "Nuclear localization of annexin Al correlates with advanced disease and peritoneal dissemination in patients with gastric carcinoma," Anatomical Record, vol. 293, no. 8, pp. 1310-1314, 2010.

[22] P. Lauren, "The two histological main types of gastric carcinoma: diffuse and so-called intestinal-type carcinoma," Acta Pathologica et Microbiologica Scandinavica, vol. 64, pp. 31-49, 1965.

[23] M. F. Dixon, R. M. Genta, J. H. Yardley et al., "Classification and grading of Gastritis: the updated Sydney system," American Journal of Surgical Pathology, vol. 20, no. 10, pp. 1161-1181, 1996.

[24] S. A. Ahrendt, J. T. Chow, S. C. Yang et al., "Alcohol consumption and cigarette smoking increase the frequency of p53 mutations in non-small cell lung cancer," Cancer Research, vol. 60, no. 12, pp. 3155-3159, 2000.

[25] L. L. Gatti, R. de Lábio, L. C. da Silva, M. D. A. C. Smith, and S. L. M. Payão, "cagA positive Helicobacter pylori in Brazilian children related to chronic gastritis," Brazilian Journal of Infectious Diseases, vol. 10, no. 4, pp. 254-258, 2006.

[26] R. M. Peek and M. J. Blaser, "Helicobacter pylori and gastrointestinal tract adenocarcinomas," Nature Reviews Cancer, vol. 2, no. 1, pp. 28-37, 2002.

[27] A. A. S. Sena, P. J. S. Provazzi, A. M. Fernandes, P. M. Cury, P. Rahal, and S. M. Oliani, "Spatial expression of two anti-inflammatory mediators, annexin 1 and galectin-1, in nasal polyposis," Clinical and Experimental Allergy, vol. 36, no. 10, pp. 1260-1267, 2006.

[28] M. C. Duarte, E. Babeto, K. R. M. Leite et al., "Expression of TERT in precancerous gastric lesions compared to gastric cancer," Brazilian Journal of Medical and Biological Research, vol. 44, no. 2, pp. 100-104, 2011. 
[29] M. W. Pfaffl, "A new mathematical model for relative quantification in real-time RT-PCR," Nucleic Acids Research, vol. 29, no. 9, article e45, 2001.

[30] M. Moghanibashi, F. R. Jazii, Z. S. Soheili et al., "Proteomics of a new esophageal cancer cell line established from Persian patient," Gene, vol. 500, pp. 124-133, 2012.

[31] J. S. Kang, B. F. Calvo, S. J. Maygarden, L. S. Caskey, J. L. Mohler, and D. K. Ornstein, "Dysregulation of annexin I protein expression in high-grade prostatic intraepithelial neoplasia and prostate cancer," Clinical Cancer Research, vol. 8, no. 1, pp. 117123, 2002

[32] J. P. Rodrigo, J. M. García-Pedrero, J. L. Llorente et al., "Downregulation of annexin $\mathrm{A} 1$ and $\mathrm{A} 2$ protein expression in intestinal-type sinonasal adenocarcinomas," Human Pathology, vol. 42, no. 1, pp. 88-94, 2011.

[33] R. Silistino-Souza, F. C. Rodrigues-Lisoni, P. M. Cury et al., "Annexin 1: differential expression in tumor and mast cells in human larynx cancer," International Journal of Cancer, vol. 120, no. 12, pp. 2582-2589, 2007.

[34] C. K. Yom, W. Han, S.-W Kim et al., "Clinical significance of snnexin A1 expression in breast câncer," Journal Breast of Cancer, vol. 14, pp. 262-268, 2011.

[35] N. Su, X.-Y. Xu, H. Chen et al., "Increased expression of annexin Al is correlated with K-ras mutation in colorectal cancer," Tohoku Journal of Experimental Medicine, vol. 222, no. 4, pp. 243-250, 2010.

[36] W.-Y Kang, W.-T Chen, Y.-C Huang, Y.-C Su, and C.-Y Chai, "Overexpression of annexin 1 in the development and differentiation of urothelial carcinoma," Kaohsiung Journal of Medical Sciences, vol. 28, pp. 145-150, 2012.

[37] Y. F. Liu, P. F. Zhang, M. Y. Li, Q. Q. Li, and Z. C. Chen, "Identification of annexin $\mathrm{Al}$ as a proinvasive and prognostic factor for lung adenocarcinoma," Clinical and Experimental Metastasis, vol. 28, no. 5, pp. 413-425, 2011.

[38] C. Y. Lin, Y. M. Jeng, H. Y. Chou et al., "Nuclear localization of annexin A1 is a prognostic factor in oral squamous cell carcinoma," Journal of Surgical Oncology, vol. 97, no. 6, pp. 544-550, 2008.

[39] T.-Y. Cheng, M.-S. Wu, J.-T. Lin et al., "Annexin A1 is associated with gastric cancer survival and promotes gastric cancer cell invasiveness through the Formyl Peptide Receptor/Extracellular Signal-Regulated Kinase/Integrin Beta-1-Binding Protein 1 Pathway," Cancer, vol. 118, no. 23, pp. 5757-5767, 2012.

[40] V. A. Alves, S. Nonogaki, P. M. Wünsch-Filho et al., "Annexin A1 subcellular expression in laryngeal squamous cell carcinoma," Histopathology, vol. 53, pp. 715-727, 2008.

[41] Y. Liu, H. X. Wang, N. Lu et al., “Translocation of annexin I from cellular membrane to the nuclear membrane in human esophageal squamous cell carcinoma," World Journal of Gastroenterology, vol. 9, no. 4, pp. 645-649, 2003.

[42] K. Monastyrskaya, E. B. Babiychuk, A. Hostettler, U. Rescher, and A. Draeger, "Annexins as intracellular calcium sensors," Cell Calcium, vol. 41, no. 3, pp. 207-219, 2007.

[43] T. H. . Sheng, L. X. Rong, Z. Y. Li, J. Bo, and S. Lei, “Tissue and serum galectin-1 expression in patients with colorectal carcinoma," Hepatogastroenterology, vol. 59, pp. 389-394, 2012.

[44] P. Kamper, M. Ludvigsen, K. Bendix et al., "Proteomic analysis identifies galectin-1 as a predictive biomarker for relapsed/refractory disease in classical Hodgkin lymphoma," Blood, vol. 117, no. 24, pp. 6638-6649, 2011.

[45] S. Saussez, C. Decaestecker, F. Lorfevre et al., "Increased expression and altered intracellular distribution of adhesion/growthregulatory lectins galectins- 1 and -7 during tumour progression in hypopharyngeal and laryngeal squamous cell carcinomas," Histopathology, vol. 52, no. 4, pp. 483-493, 2008.

[46] C. F. Estofolete, S. Zucoloto, S. M. Oliani, A. C. Polli-Lopes, and C. D. Gil, "Myenteric denervation downregulates galectin-1 and -3 expression in gastric carcinogenesis," Digestive Diseases and Sciences, vol. 56, no. 6, pp. 1637-1644, 2011.

[47] G. Chen, T. G. Gharib, C. C. Huang et al., "Discordant protein and mRNA expression in lung adenocarcinomas," Molecular \& Cellular Proteomics, vol. 1, no. 4, pp. 304-313, 2002.

[48] D. Greenbaum, C. Colangelo, K. Williams, and M. Gerstein, "Comparing protein abundance and mRNA expression levels on a genomic scale," Genome Biology, vol. 4, no. 9, article 117, 2003.

[49] Y. Guo, P. Xiao, S. Lei et al., "How is mRNA expression predictive for protein expression? A correlation study on human circulating monocytes," Acta Biochimica et Biophysica Sinica, vol. 40, no. 5, pp. 426-436, 2008.

[50] F. E. Rosa, S. M. Silveira, C. G. T. Silveira et al., "Quantitative real-time RT-PCR and chromogenic in situ hybridization: precise methods to detect HER-2 status in breast carcinoma," BMC Cancer, vol. 9, article 90, 2009.

[51] A. Bouman, M. Jan Heineman, and M. M. Faas, "Sex hormones and the immune response in humans," Human Reproduction Update, vol. 11, no. 4, pp. 411-423, 2005.

[52] E. Z. F. Ang, H. T. Nguyen, H. L. Sim, T. C. Putti, and L. H. K. Lim, "Annexin-1 regulates growth arrest induced by high levels of estrogen in MCF-7 breast cancer cells," Molecular Cancer Research, vol. 7, no. 2, pp. 266-274, 2009.

[53] J. G. Kusters, A. H. M. Van Vliet, and E. J. Kuipers, "Pathogenesis of Helicobacter pylori infection," Clinical Microbiology Reviews, vol. 19, no. 3, pp. 449-490, 2006.

[54] R. Tsutsumi, H. Higashi, M. Higuchi, M. Okada, and M. Hatakeyama, "Attenuation of Helicobacter pylori CagA.SHP2 signaling by interaction between CagA and C-terminal Src kinase," Journal of Biological Chemistry, vol. 278, no. 6, pp. 3664-3670, 2003.

[55] C. C. Allison, T. A. Kufer, E. Kremmer, M. Kaparakis, and R. L. Ferrero, "Helicobacter pylori induces MAPK phosphorylation and AP-1 activation via a NOD1-dependent mechanism," Journal of Immunology, vol. 183, no. 12, pp. 8099-8109, 2009.

[56] J. J. Yang, L. Y. Cho, S. H. Ma et al., "Oncogenic CagA promotes gastric cancer risk via activating ERK signaling pathways: a nested case-control study," PLoS ONE, vol. 6, no. 6, Article ID e21155, 2011.

[57] J. Zhou, Y. Xie, Y. Zhao, S. Wang, and Y. Li, "Human gastrin mRNA expression up-regulated by Helicobacter pylori CagA through MEK/ERK and JAK2-signaling pathways in gastric cancer cells," Gastric Cancer, vol. 14, pp. 322-331, 2011.

[58] L. L. Lin, C. N. Chen, W. C. Lin et al., "Annexin A4: a novel molecular marker for gastric cancer with Helicobacter pylori infection using proteomics approach," Proteomics, vol. 2, no. 4, pp. 619-634, 2008.

[59] L. L. Lin, H. C. Huang, S. Ogihara et al., "Helicobacter pylori disrupts host cell membranes, initiating a repair response and cell proliferation," International Journal of Molecular Sciences, vol. 13, pp. 10176-11092, 2012. 


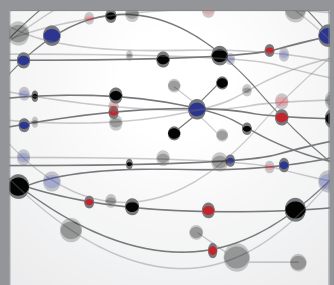

The Scientific World Journal
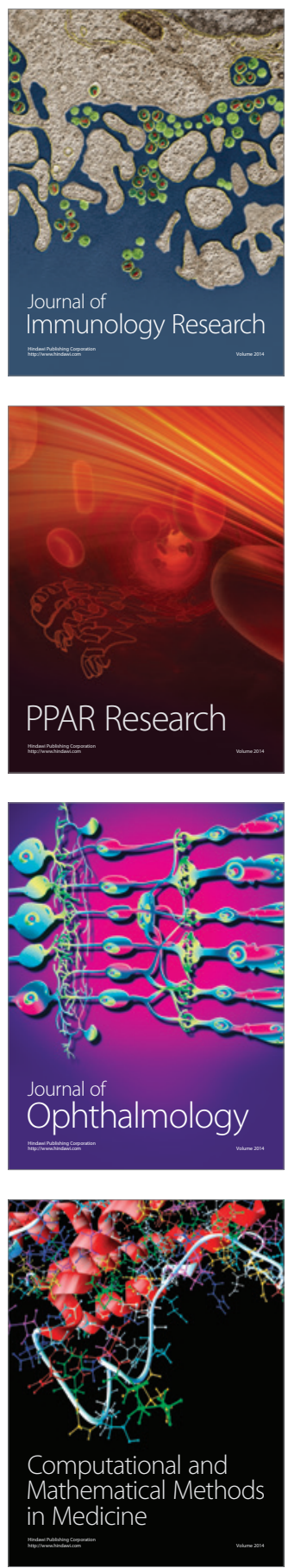

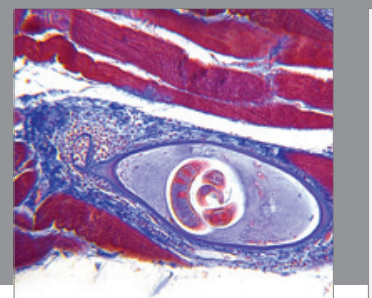

Gastroenterology

Research and Practice
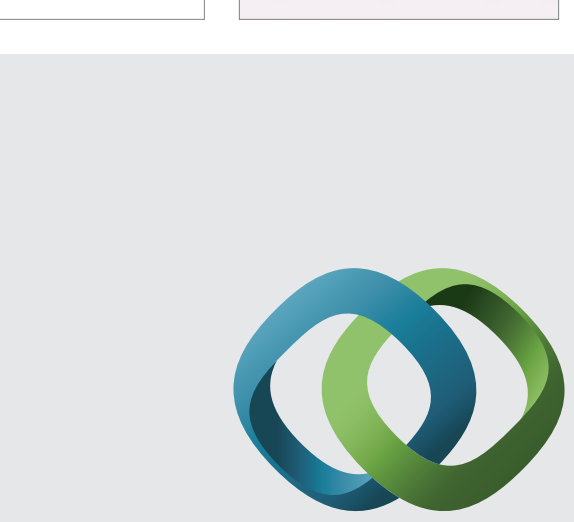

\section{Hindawi}

Submit your manuscripts at

http://www.hindawi.com
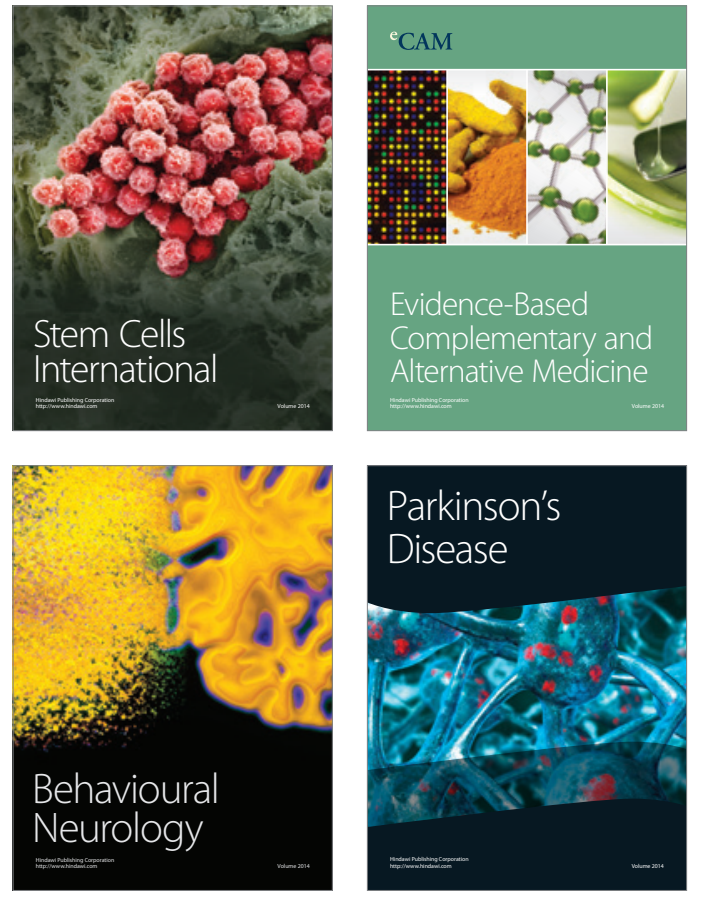
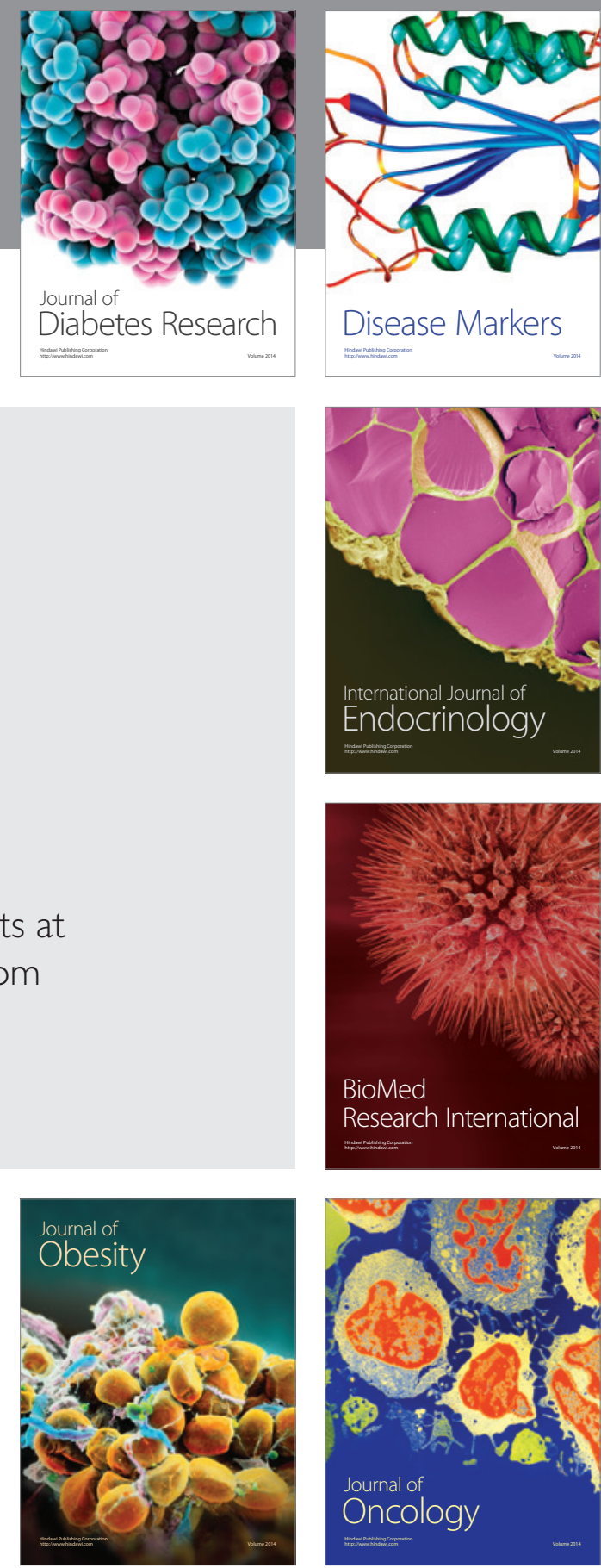

Disease Markers
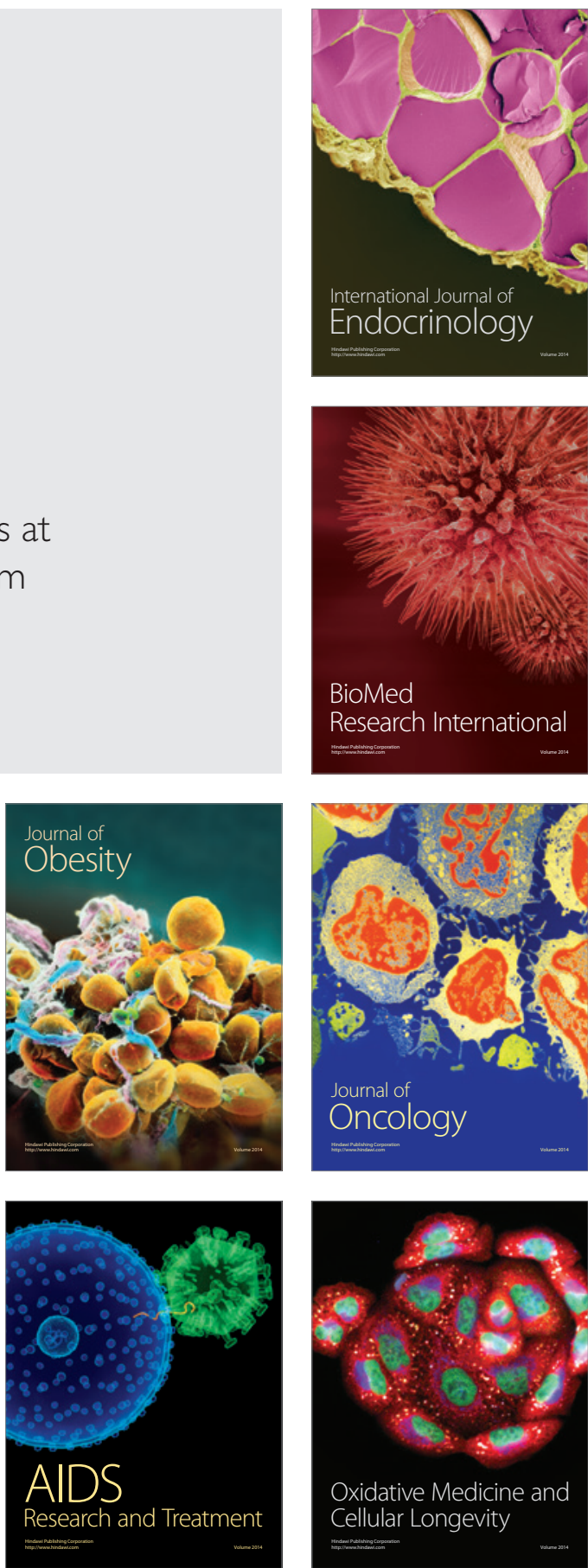